\title{
Article/Artigo
}

\section{Molecular epidemiology of hepatitis B virus among the indigenous population of the Curuçá and Itaquaí Rivers, Javari Valley, State of Amazonas, Brazil}

\author{
Epidemiologia molecular do vírus da hepatite $\mathrm{B}$ em população indígena em torno dos \\ Rios Curuçá e Itaquaí, Vale do Javari, Estado do Amazonas, Brasil
}

\section{Cristóvão Alves da Costa ${ }^{1}$ and Lucinete Okamura Kimura ${ }^{2}$}

\section{ABSTRACT}

Introduction: Hepatitis B virus (HBV) infection is one of the most serious public health problems in the world. In Brazil, HBV endemicity is heterogeneous, with the highest disease prevalence in the North region. Methods: A total of 180 samples were analyzed and subjected to polymerase chain reaction (PCR) and semi-nested PCR of the HBV S-gene, with the aim of determining the prevalence of HBV-DNA (deoxyribonucleic acid) in indigenous groups inhabiting the areas near the Curuçá and Itaquaí Rivers in the Javari Valley, State of Amazonas, Brazil. Results: The prevalence of the HBV-DNA S-gene was 51.1\% (92/180). The analysis found 18 of $49(36.7 \%)$ samples from the Marubo tribe, 68 of 125 (54.4\%) from the Kanamary, and 6 of $6(100 \%)$ from other ethnic groups to be PCR positive. There was no statistically significant difference in gender at $5 \%(\mathrm{p}=0.889)$. Indigenous people with positive PCR for HBV-DNA had a lower median age $(p<0.001)$ of 23 years. There was no statistical difference found in relation to sources of contamination or clinical aspects with the PCR results, except for fever $(\mathrm{p}<0.001)$. The high prevalence of HBV-DNA of $75 \%(15 / 20)$ in pregnant women $(\mathrm{p}=0.009)$ demonstrates an association with vertical transmission. Conclusions: The results confirm the high prevalence of HBV-DNA in the Javari Valley, making it important to devise strategies for control and more effective prevention in combating the spread of HBV.

Keywords: Hepatitis B virus. Diagnosis of HBV-DNA by PCR. Prevalence of HBV-DNA. Indigenous populations.

\section{RESUMO}

Introdução: A infecção pelo vírus da hepatite $\mathrm{B}(\mathrm{VHB})$ é um dos mais sérios problemas de saúde pública do mundo. No Brasil, a endemicidade do VHB é heterogênea, sendo a doença mais prevalente na região norte do país. Métodos: Neste estudo, foram investigadas 180 amostras de sangue por meio da técnica da reação em cadeia da polimerase (PCR) e PCR seminested para o vírus da hepatite $\mathrm{B}$, gene $\mathrm{S}$, com o intuito de determinar a prevalência do DNA (ácido desoxirribonucléico) do vírus da hepatite $\mathrm{B}$ em povos de etnias indígenas habitantes dos Rios Curuçá e Itaquaí no Vale do Javari, Estado do Amazonas, Brasil. Resultados: A prevalência encontrada para o DNA-VHB gene $S$ foi de $51,1 \%(92 / 180)$. Entre as amostras positivas $18 / 49(36,7 \%)$ pertenciam à etnia Marubo, 68/125 (54,4\%) à Kanamary e 6/6 $(100 \%)$ a outras etnias. Não houve diferença significante ao nível de $5 \%$ em relação ao gênero $(p=0,889)$. Os indígenas com PCR positiva para DNA-VHB apresentaram mediana de idade menor de 23 anos $(\mathrm{p}<0,001)$. Não foi constatado nenhuma diferença estatística em relação às fontes de contágio e o resultado da PCR, como também aos aspectos clínicos, com exceção da febre $(\mathrm{p}<0,001)$. A alta prevalência do DNA-VHB de $75 \%(15 / 20)$ em gestantes $(\mathrm{p}=0,009)$ demonstra associação com a transmissão vertical. Conclusões: Os resultados comprovam a alta prevalência do DNA-VHB no Vale do Javari, tornando-se importante traçar estratégias de controle e prevenção mais eficazes no combate à disseminação do VHB.

Palavras-chaves: Vírus da hepatite B. Diagnóstico do DNA-VHB PCR. Prevalência do DNAVHB. População indígena.

1. Laboratório de Virologia Tropical, Coordenação de Pesquisas em Ciências da Saúde, Instituto Nacional de Pesquisas da Amazônia, Manaus, AM. 2. Programa de Pós-Graduação em Ciências da Saúde, Universidade Federal do Amazonas, Manaus, AM.

Address to: Dr. Cristóvão Alves da Costa. Laboratório de Virologia Tropical/CPCS/INPA. Av. André Araújo 2936, Aleixo, 60060-001 Manaus, AM, Brasil.

Phone: 5592 3643-3288; Fax: 5592 3643-3091

e-mail: crvcosta@inpa.gov.br

Received in 11/04/2011

Accepted in 24/01/2012

\section{INTRODUCTION}

Hepatitis B virus (HBV) infection is a global health problem. Although it is preventable through vaccination, an estimated two billion people are infected around the world, with more than 350 million showing serological markers of active infection ${ }^{1}$.

The Brazilian Amazonian region is characterized as having one of the highest levels of HBV occurrence in the world, with the basins of the Juruá-Purus and Middle-Solimões Rivers showing the most elevated rates $^{2-4}$. Seroepidemiological studies among the indigenous population of this area have shown a rate of $9.7 \%$ for hepatitis B surface antigen ( $\mathrm{HBsAg}$ ) in chronic carriers ${ }^{5}$.

Research has demonstrated that in some cases serological markers are insufficient in detecting viral activity and that, in these instances, molecular tests are more sensitive and specific ${ }^{6,7}$. Deoxyribonucleic acid (DNA) detection of the virus is considered the most reliable evidence that replication and infectiousness exist ${ }^{8}$.

In the Javari Valley, the presence of HBV constitutes a particularly serious public health problem, because the indigenous population lives in isolation, often at great distances from health centers that can diagnose the disease. The nonindigenous population living in the Valley has provoked numerous disease epidemics, beyond simply hepatitis. Studies in this region are scarce, and many cases are not reported.

This study sought to determine the prevalence of HBV-DNA among indigenous peoples in the Javari Valley of the Brazilian State of Amazonas, as well as to show the epidemiological aspects of $\mathrm{HBV}$ prevalence among this population.

\section{METHODS}

A descriptive cross-sectional study was undertaken among indigenous ethnic groups that inhabit the Curuçá and Itaquaí river basins in the 
Javari Valley (Amazonas, Brazil). The prevalence of HBV-DNA was estimated using polymerase chain reaction (PCR).

The indigenous lands of the Javari Valley are located in the municipality of Atalaia do Norte, near the western limits of Amazonas on the border with Peru (Figure 1). The study population was composed of inhabitants of the indigenous communities of São Sebastião (S 0551'37.3” W 07204'53.2”), Volta Grande (S 05'37'21.6”'W 072 03’26.8”), and Pedro Lopes (S 04³2'22.6” W $\left.071^{\circ} 24^{\prime} 04.3^{\prime \prime}\right)$ on the Curuçá River, and the communities of Massapê (S 06 14'26.8” W 070³6'32.6”), Remancinho (S 0557'55.5” W $\left.070^{\circ} 37^{\prime} 07.9^{\prime \prime}\right)$, and Bananeira (S 05 $56^{\prime} 28.4^{\prime \prime} \mathrm{W} 070^{\circ} 34^{\prime} 52.1^{\prime \prime}$ ) on the Itaquaí River.

\section{Sample composition}

Allowing for a $5 \%$ sample error and a $15 \%$ error on $\mathrm{HBV}$ prevalence, a sample size of 180 was calculated. A stratified random sampling method was used, and inclusion into the sample was based simply on the order of arrival at the collection site, contingent upon the consent of the indigenous community.

Participants in the study included young and adult indigenous persons of both sexes, all of whom provided informed consent. In the case of minors, consent was given by a parent or guardian.

Samples were collected by a health technician appointed by the National Health Foundation in Atalaia do Norte/AM upon confirmation of the informed consent forms translated from the Kanamary, Kulina, Marubo, and Mayoruna languages used in these communities. Venous blood $(5 \mathrm{ml})$ was collected using disposable syringes and needles, and was stored in a Vacutainer tube containing ethylenediaminetetraacetic acid (EDTA).

The indigenous communities of São Sebastião, Volta Grande, and Pedro Lopes on the Curuçá River were visited in September 2009; the samples from the communities of Massapé, Remancinho, and Bananeira on the Itaquaí were collected in March 2010.

A form was used to obtain data on the different variables in the study: age, sex, ethnic group, indigenous community, possible sources of infection, and clinical aspects.

The molecular laboratory procedures were carried out in the virology laboratory (Coordination of Health Sciences Research of the National Institute for Research in the Amazon).

\section{Laboratory procedures}

The samples were centrifuged at 2,000rpm for $5 \mathrm{~min}$ for plasma separation, then identified with a registration number and stored at $-20^{\circ} \mathrm{C}$. For each laboratory phase, HBV-DNA positive and negative controls were used.

DNA extraction was completed using the phenol-chloroform method as described by Karasawa et al. ${ }^{9}$ and modified by Oliveira ${ }^{10}$.

The method for identifying viral DNA was PCR, followed by semi-nested PCR, with specific initiators that amplified segments of the HBV S-gene. For PCR the initiators 2821(+) 5'-GGGTCACCATATTCTTGGGAACA-3' and 783(-) 5'-CTC ACGATGCTGTACAGACT1-3' were used, which amplified the whole $S$-gene genomic segment, creating a product of $1,200 \mathrm{bp}$.

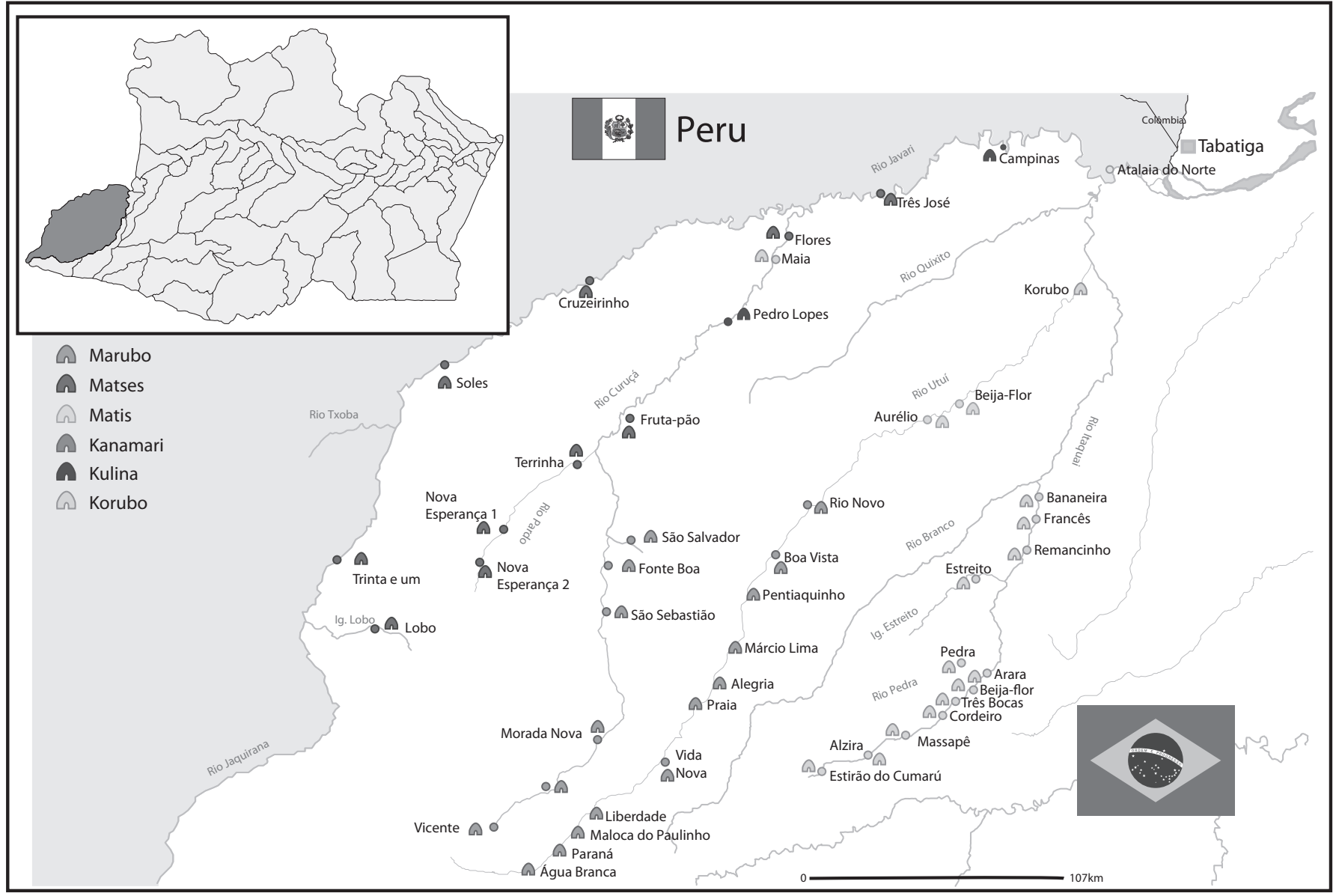

FIGURE 1 - Map of Javari Valley, State of Amazonas, Brazil (Adapted of FUNASA, 2008) 
The result of the first PCR reaction was submitted to semi-nested PCR, with the substitution of the 2821(+) initiator with P1(+) 5'TGCCTCTCACAT CTCGTCAA-3', giving a product of $680 \mathrm{bp}^{10}$.

The amplification products were submitted to agarose gel electrophoresis (1.5\%) in a tris-borate-EDTA buffer ( $\mathrm{pH} 8.3$ ), at 100 volts for one hour. A standard of $100 \mathrm{bp}$ (Invitrogen) was used, stained with ethidium bromide $(1.0 \mu \mathrm{g} / \mathrm{mL})$. DNA fragments were visualized using a transluminator and were registered with digital equipment.

\section{Analysis of the results}

The absolute and relative frequencies were calculated for the data collected. For prevalence estimation, a confidence interval of $95 \%$ (CI95\%) was used. For the age analysis, medians and quartiles (Q) were selected because normal distribution was not seen at $5 \%$ significance. In the comparison of the double entry tables, a Pearson chi-square test was used, and where it was not possible to apply, the Fisher exact test was employed. For the comparison of median age relative to PCR results, the non-parametric Mann-Whitney test was applied ${ }^{11}$.

The software utilized in the analyses was Epi-Info version 3.5.1 for Windows , and a $5 \%$ level of significance was designated for all tests.

\section{Ethical considerations}

This research is part of a wider study known as Molecular Epidemiology of Hepatitis B Virus in the Indigenous Population of Javari Valley, State of Amazonas, approved by the National Commission for Research Ethics on April 24, 2009 (registry no. 15276, evaluation no. 216/2009), and by the Research Ethics Committee of the National Institute of Amazon Research on December 5, 2008 (protocol no.189/08).

\section{RESULTS}

A total of 180 samples taken from the areas adjacent to the Curuçá and Itaquaí Rivers in the Javari Valley were analyzed. Of these samples, 49 (27.2\%) came from members of the Marubo ethnic group, 125 (69.4\%) from the Kanamary, and 6 (3.3\%) from other groups. The study population consisted of 87 (48.3\%) men and 93 (51.7\%) women.

The median age of the individuals studied was 27 years, with a range of 11 to 77 years. The age group with the highest frequency was that of 15 to 20 years (20.4\%), and quartiles $Q_{1}-Q_{3}$ were between 20 and 39. A total of 43 participants could not inform us of their age.

Of the 180 samples analyzed, 92 were PCR positive for HBV S-gene DNA, resulting in an estimated prevalence of $51.1 \%$ (Figure 2).

Table 1 shows the distribution of PCR positivity for HBV-DNA broken down by ethnic group.

In the tests for the HBV-DNA S-gene, 50.6\% of males and 51.6\% of females were PCR positive. Table 2 shows the distribution of the socio-demographic data of the positive and negative cases for HBVDNA. Of the samples studied, no statistically significant difference was found in relation to sex at $5 \%(\mathrm{p}=.889)$. However, when the mean age was compared with PCR results it was observed that PCRpositive indigenous persons showed a lower median age at 23 years $(\mathrm{p}<0.001)$ than the PCR-negative group at 33 years.

The frequency distribution of possible sources of infection did not show statistical significance relative to the PCR results at $5 \%$ for contact with persons suspected of having hepatitis B $(\mathrm{p}=0.164)$.

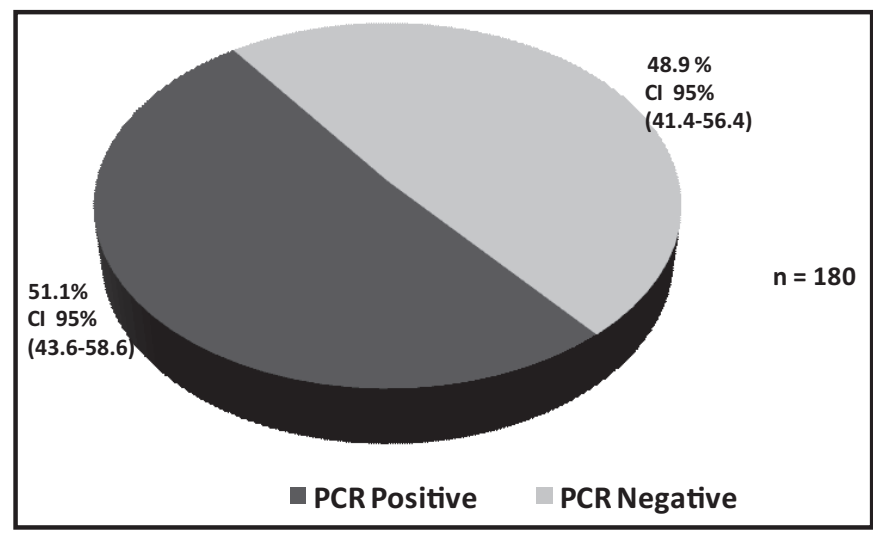

FIGURE 2 - Distribution of PCR results for HBV-DNA in the indigenous population of Javari Valley, State of Amazonas, Brazil.

PCR: polymerase chain reaction; HBV-DNA: hepatitis B virus-deoxyribonucleic acid; CI 95\%: confidence interval 95\%; n: number.

TABLE 1 - Distribution of participants by frequency of HBV-DNA PCR positivity in relation to the ethnic groups in the indigenous population of Javari Valley, State of Amazonas, Brazil.

\begin{tabular}{lccc}
\hline Ethnic group & $\mathbf{f} / \mathbf{n}$ & \% & CI 95\% \\
\hline Marubo & $18 / 49$ & 36.7 & $23.4-51.7$ \\
Kanamary & $68 / 125$ & 54.4 & $45.3-63.3$ \\
Others & $6 / 6$ & 100.0 & - \\
\hline
\end{tabular}

HBV-DNA: hepatitis B virus-deoxyribonucleic acid; PCR: polymerase chain reaction; ffrequency of PCR positive cases; $\mathbf{n}$ : number; CI 95\%: confidence interval $95 \%$.

TABLE 2 - Distribution of participants by socio-demographic data relative to the PCR results for HBV-DNA in the indigenous population of Javari Valley, State of Amazonas, Brazil.

\begin{tabular}{|c|c|c|c|c|c|c|}
\hline \multirow[b]{3}{*}{ Variables } & \multicolumn{4}{|c|}{ PCR } & \multirow[b]{3}{*}{ Total } & \multirow[b]{3}{*}{$\mathbf{p}$} \\
\hline & \multicolumn{2}{|c|}{ positive } & \multicolumn{2}{|c|}{ negative } & & \\
\hline & $\mathbf{f}_{\mathbf{i}}$ & $\%$ & $\mathbf{f}_{\mathbf{i}}$ & $\%$ & & \\
\hline Gender $(n=180)$ & & & & & & $0.889^{*}$ \\
\hline male & 44 & 50.6 & 43 & 49.4 & 87 & \\
\hline female & 48 & 51.6 & 45 & 48.4 & 93 & \\
\hline Age & & & & & & $<0.001^{* *}$ \\
\hline median & 23.0 & & 33.0 & & & \\
\hline$Q_{1}-Q_{3}$ & $18-30$ & & $22-44$ & & & \\
\hline
\end{tabular}

PCR: polymerase chain reaction; HBV-DNA: hepatitis B virus-deoxyribonucleic acid Qi: quartile; fi: simple frequency; ${ }^{*}$ Pearson chi-square test; ${ }^{* *}$ Mann-Whitney non-parametric test; $p$-value in bold italics indicates statistical difference at a level of $5 \%$.

The same was true for having a suspected case of hepatitis in the family, tattoos $(p=0.420)$, dental extraction $(p=0.781)$, sharing of undergarments, sharing of toothbrushes $(\mathrm{p}=0.364)$, sharing of razors, skin wounds, and frequent departure from the village $(\mathrm{p}=0.271)$.

In the group of participants that declared they had recently been febrile, $80 \%$ (12/15) were HBV-DNA positive and 20\% (3/15) were negative, with a statistical difference at $5 \%(\mathrm{p}<0.001)$. Among those that presented no fever, $28.6 \%(12 / 42)$ and $71.4 \%(30 / 42)$ presented positive and negative results, respectively, for HBV DNA.

During the study, 20 (21.5\%) women indicated they were pregnant, with $75 \%(15 / 20)$ positive and $25 \%(5 / 20)$ negative for HBV-DNA, showing a statistical difference $(5 \%)$ of $\mathrm{p}=0.009$ in relation to the PCR results. Among those who were not pregnant, 40.4\% (21/52) were HBV-DNA positive and 59.6\% (31/52) were negative. However, a statistically significant difference was not seen 
for having received hepatitis $B$ vaccine $(p=0.748)$, or for malaise $(p=0.799)$, nausea $(p=0.550)$, jaundice, pain in the liver area $(\mathrm{p}=0.146)$, myalgia $(\mathrm{p}=0.552)$, arthralgia $(\mathrm{p}=0.832)$, or darkened urine $(\mathrm{p}=0.438)$.

As for the distribution by frequency of HBV-DNA positivity for each river and indigenous community of the Javari Valley, 24 (43.6\%) of 55 samples from the Curuçá River were positive, with $8(21.6 \%)$ of 37 coming from the indigenous community of São Sebastião, 10 (83.3\%) of 12 from Volta Grande, and 6 (100\%) of 6 from Pedro Lopes. Of the samples from the Itaquaí River, 68 of 125 were positive for HBV DNA, for a $54.4 \%$ prevalence. Broken down by community, 32 (57.1\%) of 56 were positive in Massapê, 13 (34.2\%) of 38 in Remancinho, and 23 (74.2\%) of 31 in Bananeira.

\section{DISCUSSION}

Epidemiological studies on hepatitis B in Brazil are rare, despite the fact that it is a major public health issue. Its frequency is still underestimated, considering that many infected individuals are asymptomatic and symptomatic infections are underreported ${ }^{12}$.

The Amazon region presents the highest endemicity of HBV in Brazil, especially among indigenous peoples ${ }^{5,13,14}$. However, the epidemiological aspects and the transmission of $\mathrm{HBV}$ infection in the Amazon region are not clear, particularly the conditions that favor high prevalence ${ }^{3,15}$.

The results of this study confirm the high prevalence of HBVDNA, estimated at $51.1 \%$, in the indigenous communities of the Curuça and Itaquaí Rivers in the Javari Valley of Amazonas state. This information is in line with other findings in which similar prevalence figures were found ${ }^{16,17}$. Barros-Junior et al. ${ }^{18}$ reported a lower prevalence in 51 (17.6\%) patients of the Brazilian Amazon. In studies conducted in the States of Bahia and Mato Grosso do Sul the prevalence was $18 \%$ and $24.7 \%^{19,20}$, respectively, showing that HBV-DNA prevalence is quite heterogeneous in Brazil.

Oliveira $^{10}$, in a study done among outpatients of the Tropical Medicine Foundation in the municipality of Lábrea, Amazonas, found an $85 \%$ prevalence of HBV-DNA in patients with serological confirmation of hepatitis $\mathrm{B}$. We believe that this difference in prevalence is due to the fact that the samples were chosen from patients who tested positive for HBsAg, hepatitis B e antigen ( $\mathrm{HBeAg})$, or total antibody against hepatitis B core antigen (anti-HBc), as opposed to the present study in which participants were included randomly. According to Fonseca ${ }^{21}$, serological markers assist in the diagnosis of $\mathrm{HBV}$ infection.

A number of works in the literature have used serological markers in indigenous peoples ${ }^{2,3,5,15,22}$. All these studies also report a high prevalence of $\mathrm{HBV}$.

This study shows a 54.4\% HBV-DNA prevalence in the Kanamary tribe, $36.7 \%$ in the Marubo, and $100 \%$ in other ethnic groups. The Marubos have been in contact with non-indigenous cultures for 150 years and the Kanamary for around 35. The border area between Brazil and Peru facilitated access to Javari Valley, leading to environmental exploitation and the dissemination of disease ${ }^{23,24}$. It is still up for discussion whether this is an element for the propagation of $\mathrm{HBV}$ in the villages.

In studies conducted by Braga et al. ${ }^{5}$ and Ferreira et al. ${ }^{25}$ in different tribes of the Amazon, HBV infection was shown to be less prevalent in indigenous groups that have little contact with non- indigenous cultures, which is backed up by our research. It is worth mentioning, however, that the majority of Marubos live in settlements near the Curuçá River and that the collection of samples in this area was done in September 2009, coinciding with the entry of influenza A $\left(\mathrm{H}_{1} \mathrm{~N}_{1}\right)$ in Brazil. This event caused considerable fear and mistrust among indigenous persons, and as a result fewer of them consented to participate in the study, thereby resulting in the collection of only 55 samples.

Analysis of the gender of the study population showed more female participants largely due to their being in charge of the domestic workload and small farms. Thus, women were more present in the villages, with the men either hunting or being farther from home. The research of Viana et al. ${ }^{26}$ of Amerindians and non-Amerindians in the western part of the State of Acre was also characterized by a predominance of women relative to men.

As for the results of PCR positivity for HBV-DNA in the study, we found no statistically significant difference by gender. This goes against some studies that indicate greater prevalence among men ${ }^{17,19}$ and other studies that show a higher caseload among women ${ }^{22}$. It is the view of the researchers, however, that men are probably more exposed to sources of infection due to behavioral aspects such as drug use, promiscuity, infrequent prophylactic use, greater frequency of travel outside of the indigenous areas, and decorative body piercings.

In relation to the age groups of the study participants, younger indigenous persons (median age 23) were found to have higher positivity for HBV-DNA/PCR. This outcome shows that sexual transmission is significant in this group with many members at a sexually active age. Several studies reinforce the effect of this behavior ${ }^{10,27,28}$.

With regard to the sources of infection and the presence of HBVDNA, no statistical difference was found. It has been suggested that the transmission of HBV between family members is important in areas of high endemicity. Research done by Lobato et al. ${ }^{29}$ on pregnant women participating in the pre-natal program in the municipality of Rio Branco, State of Acre, Brazil, confirms intrafamilial transmission of HBV between brothers/sisters, parents, sexual partners, children, and those who share the use of a toothbrush. Several studies also suggest the transmission of HBV by mosquitoes ${ }^{30-32}$.

In the survey found was the presence of some variables with missing values, since the indigenous people could not inform us some variables, which resulted in the impossibility of identifying other sources of HBV infection.

In the evaluation of the clinical aspects related to PCR results for HBVDNA, this study did not find any statistical significance for the following variables: malaise, nausea, jaundice, liver pain, myalgia, arthralgia, and darkened urine. On the other hand, fever was statistically significant among participants who had this symptom and were PCR positive (80\%). This suggests the occurrence of other febrile diseases not exclusive to hepatitis B. In the Amazon, infection with HBV and Plasmodium falciparum is quite common, as are co-infections ${ }^{32}$. A study undertaken by Viana et al. $^{26}$ also relates case histories of malaria and jaundice association.

In the Javari Valley, malaria is highly endemic ${ }^{23,33}$. We believe it is necessary to conduct other studies of diseases that present the same pattern of fever, especially arboviruses, that are present in the Amazon.

In areas where hepatitis B is highly endemic, the virus is frequently transmitted during childhood, either by HBV-carrier mothers to their newborns or during pregnancy/childbirth. The chances of transmission increase as the pregnancy comes to term and are much higher in acute carriers than in chronic ones ${ }^{34}$. 
Our research showed that $75 \%$ of the pregnant women involved in the study were HBV-DNA positive by PCR. This outcome suggests the existence of vertical HBV transmission in the Javari Valley. Unfortunately, however, it was not possible to verify this occurrence since the study did not include samples from newborns and children. The age range of the study group was only 11 to 77 years of age. The percentage of HBV-DNA found in the pregnant women reveals the vulnerability to viral transmission and infection despite the availability of hepatitis B vaccination.

This vaccine is the most effective way to prevent acute or chronic infection and to eliminate transmission in all age groups ${ }^{35}$. In the present study, it was not possible to evaluate the effects of vaccine, since the indigenous people could not inform us whether they had taken three doses, reporting only that they were vaccinated and there was no information of their anti-HBs (antibody to HBsAg), notwithstanding efforts by the National Health Foundation to develop immunization campaigns in Javari Valley ${ }^{33}$.

In the present study, the prevalence of HBV-DNA in the Curuçá and Itaquaí river basins was $43.6 \%$ and $54.4 \%$, respectively. It is interesting to note that the indigenous communities closest to the City of Atalaia do Norte had the highest rates, as seen in the community of Pedro Lopes (100\%) on the Curuçá River and Bananeira (74.2\%) on the Itaquaí. This suggests the influence of environmental, geographical, and epidemiological factors in the dissemination of HBV, especially contact with neighboring non-indigenous population groups. Several studies back this hypothesis s $^{5,25,36}$

The results of this study provide evidence of the high prevalence of HBV-DNA in the Javari Valley and highlight the importance of developing more effective control and prevention strategies to combat the spread of HBV. Further research will be needed in the future to verify the association between HBV and HDV (hepatitis D Virus), as well as to identify the HBV genotypes present in the Javari Valley so as to better evaluate the association between genotype, clinical evolution of infection, treatment response, and ethnic origin.

\section{ACKNOWLEDGMENTS}

We thank the Marubo Association of São Sebastião, the Union of Indigenous Peoples of Javari Valley, the State Secretariat for Indigenous Groups, and the National Institute of Amazon Research.

\section{CONFLICT OF INTEREST}

The authors declare that there is no conflict of interest.

\section{FINANCIAL SUPPORT}

This study received financial support from the Brazilian Federal Ministry of Health, the Pan American Health Organization, the National Council on Scientific Development, and the National Health Foundation.

\section{REFERENCES}

1. Roncato M, Ballardin PAZ, Lunge VR. Influência dos genótipos no tratamento da hepatite B. Rev HCPA 2008; 28:188-193.

2. Alecrim WD, Marreiros LS, Alecrim MGC, Santos MIKF. Inquérito sobre presença de HBsAg em habitantes de Lábrea, Amazonas. Rev Soc Bras Med Trop 1986; 19:58-59.
3. Bensabath G, Hadler SC, Soares MCP, Fields H, Dias LB, Popper H, et al. Hepatitis Delta virus infection and Labrea hepatitis. Prevalence and role in fulminant hepatitis in the Amazon basin. JAMA 1987; 258:479-483.

4. Fonseca JCF, Brasil LM, Castilho MC, Souza RAB, Braga WSM. The occurence of increased rates of HAV, HBV and HDV infection in a isolated village, Ipixuna, Amazonas, Brasil Hepatol 1994; 19:63I.

5. Braga WSM, Brasil LM, Souza RAB, Castilho MC, Fonseca JC. Ocorrência da infecção pelo vírus da hepatite $\mathrm{B}(\mathrm{VHB})$ e delta (VHD) em sete grupos indígenas do Estado do Amazonas. Rev Soc Bras Med Trop 2001; 34:349-355.

6. Allain JP. Occult hepatitis B virus infection: implications in transfusion. Vox Sang 2004; 86:83-91.

7. Raimondo G, Pollicino T, Cacciola I, Squadrito G. Occult hepatitis B virus infection. J Hepatol 2007; 46:160-170.

8. Silva CMD, Niel C. Hepatite B. In: Rossetti ML, Silva CMD, Rodrigues JJS editors. Doenças Infeciosas: diagnóstico molecular. Rio de Janeiro: Guanabara Koogan; 2006. p.112.

9. Karasawa T, Aizawa Y, Zeniya M, Kuramoto A, Shirasawa T, Toda G. Genetic heterogeneity in the precore region of hepatitis $\mathrm{B}$ virus in hepatitis $\mathrm{B}$ e antigennegative chronic hepatitis B patients: spontaneous seroconversion and interferoninduced seroconversion. J Med Virol 1995; 45:373-380.

10. Oliveira CM. Análise molecular e implicações biológicas do vírus da hepatite B, em pacientes naturais do Estado do Amazonas. [Doctors Thesis]. [Manaus] Universidade Federal do Amazonas; 2007. 135 p.

11. Vieira S. Bioestatística, tópicos avançados. $2^{\text {nd }}$ Edition. Rio de Janeiro: Elsevier 2004.

12. Ferreira CT, Silveira CT. Hepatites virais: aspectos da epidemiologia e da prevenção. Rev Bras Epidemiol 2004; 7:473-487.

13. Azevedo RA, Silva AE, Ferraz MLG, Marcopito LF, Baruzzi RG. Prevalência dos marcadores sorológicos dos vírus da hepatite $\mathrm{B}$ e $\mathrm{D}$ em crianças das tribos Caiabi e Txucarramãe do Parque Indígena do Xingu, Brasil, Central. Rev Soc Bras Med Trop 1996; 29:431-439.

14. FerrariJO, Ferreira MU, Tanaka A, Mizokami M. The seroprevalence of hepatitis $\mathrm{B}$ and $\mathrm{C}$ in an Amerindian population in the southwestern Brazilian Amazon. Rev Soc Bras Med Trop 1999; 32:299-302.

15. Fonseca JCF. Epidemiologia das hepatites B e Delta na região Amazônica. Skopia $1988 ; 23: 28-32$

16. Dias ALB. Caracterização molecular do vírus da hepatite B (VHB) em portadores de área endêmica na Amazônia Ocidental Brasileira. [Masters Dissertation] [Manaus]: Universidade do Estado do Amazonas; 2009. 45 p.

17. Victoria FS, Oliveira CMC, Victoria MB, Victoria CB, Ferreira LCL. Characterization of HBeAg-Negative chronic hepatitis B in western Brazilian Amazonia. Braz J Infect Dis 2008; 12:27-37.

18. Barros-Junior GM, Braga WSM, Oliveira CMC, Castilho MC, Araújo JR Hepatite crônica B oculta: prevalência e aspectos clínicos em população de elevada endemicidade de infecção pelo vírus da hepatite B na Amazônia ocidental brasileira. Rev Soc Bras Med Trop 2008; 41:596-601.

19. Almeida D, Tavares-Neto J, Trepo C, Almeida A, Mello C, Chemin I, et al. Occult $B$ infection in the brasilian northeastern region: a preliminary report. Braz J Infect Dis 2008 ; $12: 310-312$.

20. Motta-Castro ARC, Martins RMB, Araujo NM, Niel C, Facholi GB, Lago BV et al. Molecular epidemiology of hepatitis B virus in an isolated Afro-Brazilian community. Arch Virol 2008; 153:2197-2205.

21. Fonseca JCF. História natural da hepatite crônica B. Rev Soc Bras Med Trop 2007; 40:672-677.

22. Nunes HM, Monteiro MRCC, Soares MCP. Prevalência dos marcadores sorológicos dos vírus das hepatites $\mathrm{B}$ e $\mathrm{D}$ na área indígena Apyterewa, do grupo Parakanã, Pará, Brasil. Cad Saude Publica 2007; 23:2756-2766.

23. Conselho Indigenista Missionário (CIMI). I Seminário: Saúde e Gestão territoria e Aproveitamento Sustentável do Vale do Javari [Internet]. Manaus: CIMI; 2009 [Cited 2010 April]. Available from: http://www.cimi.org.br/site/pt-br/?system $=$ news\&action $=$ read\&id $=3938$

24. União dos Povos Indígenas do Vale do Javari (UNIVAJA). Atalaia do Norte, Povos Indígenas [Internet]. [Cited $2010 \mathrm{March}$ ]. Available from: htm://www. feis.unesp.br/grupos-associacoes/civaja/index.htm1. 
25. Ferreira A, Greca D, Tavares E, Moriya Y, Spelling F, Boeira M, et al. Soroepidemiologia da hepatite B e C em índios Kaingang do Sul do Brasil. Rev Paname Salud Publica 2006; 20:230-235.

26. Viana S, Paraná R, Moreira RC, Compri AP, Macedo V. High prevalence of hepatitis $\mathrm{B}$ virus and hepatitis $\mathrm{D}$ virus in the western brazilian amazon. Am J Trop Med Hyg 2005; 73:808-814.

27. Clemens SAC, Fonseca JC, Azevedo T, Cavalcanti A, Silveira TR, Castilho MC, et al. Soroprevalência para hepatite A e hepatite B em quatro centros no Brasil. Rev Soc Bras Med Trop 2000; 33:1-10.

28. Paula VS, Arruda ME, Vitral CL, Gaspar AMC. Seroprevalence of viral hepatitis in riverine communities from the Western region of the Brazilian Amazon Basin. Mem Inst Oswaldo Cruz 2001; 96:1123-1128.

29. Lobato C, Tavares-Neto J, Rios-Leite M, Trepo C, Vitvitski L, Parvaz P, et al. Intrafamilial prevalence of hepatitis B virus in Western Brazilian Amazon region: Epidemiologic and biomolecular study. J Gastroenterol Hepatol 2006; 21:863-868.

30. Iversson LB, Granato CFH, Travassos da Rosa A, Pannuti CS. Relationship between the prevalence of antibodies to hepatitis B core antigen and arbovirus in fishermen from the Ribeira Valley, Brazil. Rev Inst Med Trop São Paulo 1990; 32:215-220.
31. Chanteau S, Sechan Y, Moulia-Pelat JP, Luquiaud P, Spiegel A, Boutin JP, et al. The blackfly Simulium buissoni and infection by Hepatitis B virus on a Holoendemic Island of the Marquesas Archipelago in French Polynesia. Am J Trop Med Hyg 1993; 48:763-770.

32. Braga WSM, Silva EB, Souza RAB, Tosta CE. Soroprevalência da infecção pelo vírus da hepatite B e pelo plasmodium em Lábrea, Amazonas: estimativa da ocorrência de prováveis coinfecções. Rev Soc Bras Med Trop 2005; 38:218-223.

33. Fundação Nacional de Saúde (FUNASA). Boletim Informativo Especial. Brasília: FUNASA; 2008.

34. Roingeard P, Diouf A, Mboup S, Diadhiou F, Essex M. Perinatal transmission of hepatitis B virus in Senegal. Paper presented at: $8^{\text {th }}$ International Symposium on Viral Hepatitis and Liver Disease; 1993; Abstract Book (Number 143); Tokyo, Japan.

35. Center for Disease Control and Prevention (CDC). Guidelines for viral hepatitis surveillance and case management. Recommendations and Reports. MMWR 2002; June:1-43.

36. Quintero A, Uzcategui N, Loureiro CL, Villegas I, Illarramendi X, Guevara ME. Hepatitis delta virus genotypes I and III circulate associated with hepatitis B virus genotype F in Venezuela. J Med Virol 2001; 64:356-359. 